\title{
SADAR FINANSIAL: PELATIHAN MENGGUNAKAN INFORMASI DIGITAL DALAM MENGGALI TUJUAN MENABUNG PADA ANAK
}

\author{
Michael Christian* \\ Program Studi Manajemen, Universitas Bunda Mulia
}

\begin{abstract}
Almost all age groups have a difficult tendency in saving, especially in groups of children. Various ways that can be done in educating children in saving. Savings products for children from various Banks both public and private can be utilized in getting used to saving. Understanding the amount of savings that can be saved in a certain period of time should be known early on. It aims to prepare knowledge in children for discipline in saving and wise in the use of savings in the future. Through training in the form of the use of digital information in digging the goal of saving children is expected to be educated children about the discipline in saving, the amount of savings to be achieved and its use in realizing the wishes of children in the future. This research involves children from elementary school (SD) to high school (SMA) at the Orphanage. The results of this training explains that materials and implementations aimed at educating children in terms of savings that utilize digital information provide benefits and knowledge to participants. The ability factor of instructor/speaker is effective in giving the material to the participants. Device tools integrated with the Internet and the ability of participants to use digital information in terms of saving is still minimal and need to be familiarized.
\end{abstract}

Keywords: Saving, Children, Digital Information, Training

\begin{abstract}
ABSTRAK
Hampir semua kelompok usia memiliki kecenderungan sulit dalam menabung, terutama pada kelompok anak. Berbagai cara yang dapat dilakukan dalam mengedukasi anak dalam menabung. Produk-produk tabungan untuk anak dari berbagai Bank baik milik pemerintah maupun swasta dapat dimanfaatkan dalam membiasakan diri untuk menabung. Pemahaman dan pemikiran anak terhadap jumlah tabungan yang dapat ditabung dalam kurun waktu tertentu sebaiknya diketahui sejak dini. Hal ini bertujuan untuk mempersiapkan pengetahuan pada anak untuk disiplin dalam menabung dan bijak dalam penggunaan tabungannya di kemudian hari denga berbagai kebutuhan. Melalui pelatihan berbentuk penggunaan informasi digital dalam menggali tujuan menabung pada anak diharapkan anak dapat diberikan edukasi mengenai disiplin dalam menabung, jumlah tabungan yang akan dicapai dan penggunaannya dalam mewujudkan keinginan anak di masa yang akan datang. Penelitian yang dilakukan ini melibatkan anak-anak yang berusia Sekolah Dasar (SD) sampai dengan Sekolah Menengah Atas (SMA) di Panti Asuhan. Hasil dari pelatihan ini menjelaskan bahwa materi dan implementasi yang bertujuan dengan edukasi anak dalam hal menabung yang memanfaatkan informasi digital memberikan manfaat dan pengetahuan kepada para peserta. Faktor kemampuan instruktur/narasumber efektif dalam memberikan materi kepada peserta. Perangkat gawai yang terintegrasi dengan internet dan kemampuan peserta dalam menggunakan informasi digital dalam hal menabung dirasa masih minim dan perlu untuk dibiasakan.
\end{abstract}

Kata Kunci: Menabung, Anak, Informasi Digital, Pelatihan

*email: michaelchristianid@gmail.com 


\section{Latar Belakang}

Berdasarkan konvensi internasional, individu masih masuk dalam kelompok anakanak sampai dengan usia 18 tahun (kompas.com, 2011) yang dalam kaitan hal ini adalah bahwa orang tua diharuskan untuk memenuhi kebutuhan setiap anak. Kebutuhan dalam hal ini juga memiliki arti pengetahuan atau wawasan dalam hal yang baik, salah satunya menabung. Hampir semua kelompok usia memiliki kecenderungan sulit dalam menabung, terutama pada kelompok anak. Sedikit mengingat peribahasa "ala bisa karena biasa" mungkin tepat untuk mengedukasi kegiatan menabung pada anak. Menurut seorang psikolog dari Universitas Indonesia, memberikan edukasi dalam hal menabung harus dibiasakan secara konsisten sejak dini terutama pada anak usia sekolah karena pada periode ini anak-anak lebih mudah diberikan pemahaman (Widjaya, 2012).

Konsistensi dalam memberikan edukasi terletak pada kreativitas cara orangorang terdekat (seperti orang tua) dalam mengajari anak. Berbagai cara yang dapat dilakukan dalam mengedukasi anak dalam menabung menurut situs treasurer.franklincountyohio.gov yang dikutip dalam Setiawan (2013), mengedukasi anak dalam menabung dalam dilakukan dengan memberikan informasi-informasi pada anak seperti menabung dapat dilakukan dari uang kembalian, menabung dapat dimulai dari rumah, memberikan pengertian motivasi tujuan menabung, dan memberikan pengertian bahwa dengan menabung dapat mendapatkan barang yang diinginkan (hadiah). Hal ini menjelaskan bahwa titik awal dalam mengedukasi anak untuk terbiasa menabung adalah memberikan pengertian yang konsisten pentingnya menabung untuk tujuan tertentu yang ingin dicapai. Hal ini senada dengan pernyataan yang diberikan oleh salah seorang anggota dewan di Sumatera Utara, bahwa salah satu manfaat yang dapat diperoleh dari menabung pada anak adalah terarahnya kelangsungan pendidikan anak (Kaban, 2017).

Hal-hal di atas yang menyangkut pentingnya menabung merupakan hal yang sudah lumrah ditemukan di masyarakat dari dahulu kala. Dewasa ini seiring dengan perkembangan teknologi informasi, maka daya serap dan berpikir anak sangat erat dipengaruhi oleh lingkungan. Lingkungan dalam hal dapat berarti bahwa daya pakai uang yang dimiliki nanti perlulah diperjelas. Hal ini berarti bahwa menabung sebaiknya tidak hanya sekedar hanya edukasi konsistensi menyimpan uang sisa atau sebagian uang yang didapat anak, namun sudah harus mengarah ke bentuk tabungan yang lebih mendekatkan dengan tujuan anak menabung. Tingkat inflasi akan terus memengaruhi harga di hamper semua sektor termasuk pendidikan yang menjadi salah satu tujuan penting dalam menabung. Periode menabung dan harga pasar nyatanya sering tidak berbanding lurus, di mana dalam hal ini periode menabung biasanya cenderung lebih lambat atau memiliki keterbatasan. Oleh karena itu menurut Inayati (manajer cabang BNI Syariah Banjarbaru) selain memberikan edukasi mengenai tujuan menabung, anak juga perlu diperkenalkan dengan bank yang lebih dapat mengatur periode menabung dan memiliki program-program yang lebih disukai anak dibanding menabung secara konvensional di rumah (Rahman, 2017). Edukasi untuk mengenalkan anak-anak usia dini seperti anakanak di Sekolah Dasar (SD) juga digalakkan oleh Otoritas Jasa Keuangan dengan melibatkan beberapa perusahan di industri perbankan dan lembaga keuangan lainnya, seperti Bank MNC yang memberikan nilai edukasi keamanan yang secara langsung diperoleh sebagai nasabah bila menabung di bank (Fuad, 2017) . Hal ini mengartikan bahwa pemerintah dewasa ini memberikan atensi yang lebih pada masyarakat dengan usia dini di mana bank merupakan media yang tepat untuk mengedukasi kebiasaan menabung dengan tingkat keamanan yang terjamin dan program menarik yang disukai anak.

Kesiapan bank-bank di Indonesia dalam menyediakan produk tabungan untuk anak semakin gencar dan banyak dibuat. Bank CIMB Niaga melalui produk CIMB Junior Niaga Tabungan Junior memberikan kemudahan dengan setoran pertama sebesar Rp. 100.000, diskon menarik di beberapa tempat bermain anak seperti Toys City, Waterboom, dan Snow Bay, dan juga memberikan suku bunga progresif yakni $2 \%$ per tahun (cimbniaga.com, 2018). Maybank dengan produknya Tabungan Superkidz memberikan kemudahan setoran awal sebesar Rp. 100.000, saldo minimum sebesar Rp. 20.000 dan bebas biaya administrasi (maybank.co.id, 2018). 
Lainnya halnya dengan Bank Panin melalui produk yang dikenal dengan Panin Tabungan Junior yang menekankan pada hal-hal seperti suku bunga kompetitif, kemudahan pembukaan rekening, dan kartu Anjungan Tunai Mandiri (ATM) yang serba bisa (www.panin.co.id, 2018). Bank-bank plat merah seperti Bank Rakyat Indonesia (BRI) dan Bank Negara Indonesia 46 (BNI 46) juga memiliki produk tabungan anak yang disebut dengan Britama Junio dan BNI Taplus Anak. Britama Junio memiliki kemudahan dalam setoran awal sebesar Rp. 150.000 dan kemudahan aksesibilitas jaringan kartu Debit dan dapat bertransaksi di 18.000 ATM BRI di Indonesia (bri.co.id, 2018), sedangkan BNI 46 melalui produk BNI Taplus Anak mengutamakan edukasi menabung pada anak seperti membiasakan anak belajar menabung, memberikan kesempatan kepada anak untuk melakukan transaksi sendiri di ATM dan belanja di toko, serta nama dan foto anak pada buku tabungan dan kartu debit (BNI Taplus Anak, 2018).

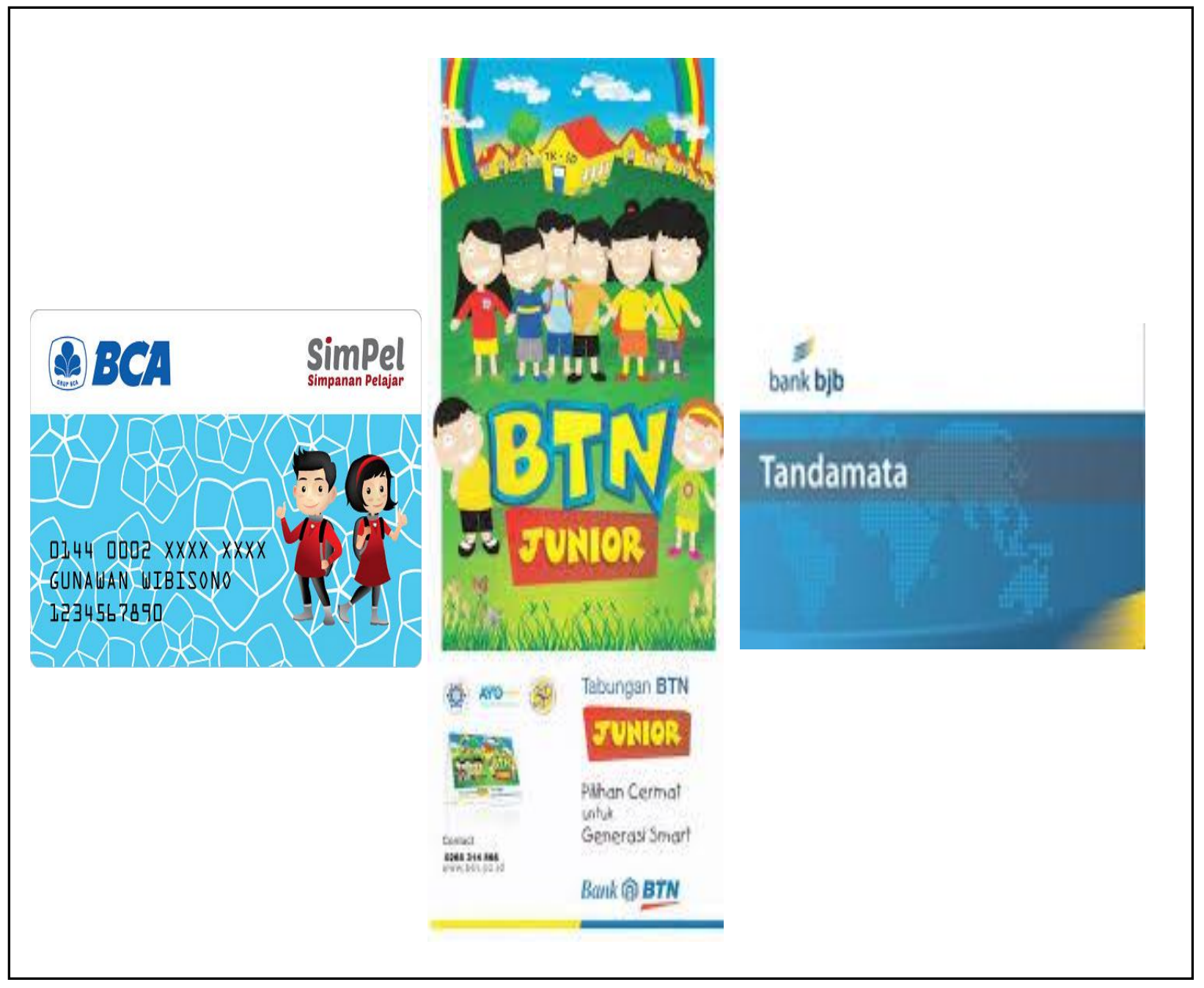

Sumber: berbagai sumber daring

Gambar 1. Kalkulator Tabungan 
Tabel 1. Produk Tabungan Anak di Indonesia

\begin{tabular}{|c|c|c|c|}
\hline No & Nama Produk Tabungan & Bank & Kategori \\
\hline 1 & BNI Taplus Anak & BNI 46 & \multirow{5}{*}{ Bank BUMN } \\
\hline 2 & Britama Junio & BRI & \\
\hline 3 & BTN Junior & BTN & \\
\hline 4 & BJB Tandamata Myfirst & BJB & \\
\hline 5 & CIMB NIaga Tabungan Junior & CIMB Niaga & \\
\hline 6 & Maybank Tabungan Superkidz & Maybank & \multirow{3}{*}{ Bank Swasta } \\
\hline 7 & Panin Bank Tabungan Junior & Bank Panin & \\
\hline 8 & Mega Perdana & Bank Mega & \\
\hline
\end{tabular}

Sumber: berbagai sumber daring

Beberapa dari bank di atas memiliki kemudahan dan manfaat dari nilai bunga per tahun yang diberikan. Dalam mencapai tujuan menabung pada anak, nilai bunga tersebut dapat lebih membantu mewujudkan tujuan anak. Hal ini disebabkan karena nilai bunga dapat membantu untuk mengetahui jumlah tabungan yang akan diperioleh dalam jangka waktu tertentu. Anak juga dapat diberikan edukasi untuk turut serta menghitung dan mencari tahu besarnya jumlah tabungan dalam periode waktu yang ingin ditentukan oleh anak (missal: 5 tahun, 10 tahun, 15 tahun, dan sebagainya). Di beberapa media informasi, hal ini disebut dengan kalkulator uang. Anak sebagai generasi millennial ke atas dapat lebih dekat dan mungkin tidak asing dengan aplikasi ini karena dapat ditemukan di situs-situs bank ataupun portal informasi seperti situs MSN yang disediakan oleh Microsoft (www.msn.com, 2018). Aplikasi tersebut memungkinkan pengguna untuk melakukan kustomisasi pada jumlah sasaran tabungan dan jumlah tabungan sekarang (dalam rupiah), bunga tahunan (dalam $\%$ ) yang disesuaikan dengan fasilitas bank masing-masing, pemajemukan dan jumlah tahun untuk menabung (dalam n-tahun). Informasi yang kemudian dapat diperoleh dari aplikasi ini adalah anak dapat diedukasi dengan diberikan informasi mengenai jumlah yang sebaiknya harus ditabung untuk mewujudkan jumlah tabungan yang ingin dicapai dalam periode tertentu.

Edukasi sadar finansial pada anak dapat diberikan dengan cara yang menyenangkan dengan aplikasi tersebut yaitu dengan cara mengitung, melakukan kustomisasi, dan belajar memotivasi diri untuk mencapai jumlah tabungan yang diinginkan. Oleh karena itu, penerapan edukasi ini sebaiknya dilakukan dengan cara yang sederhana (tidak terkesan formil) dan menyenangkan supaya anak merasa nyaman dan tidak terkesan rumit. Pemberikan edukasi melalui aplikasi ini sejatinya dapat membantu peran orang tua dan guru di sekolah sebagai peran pertama yang memberikan edukasi pentingnya menabung pada anak. 


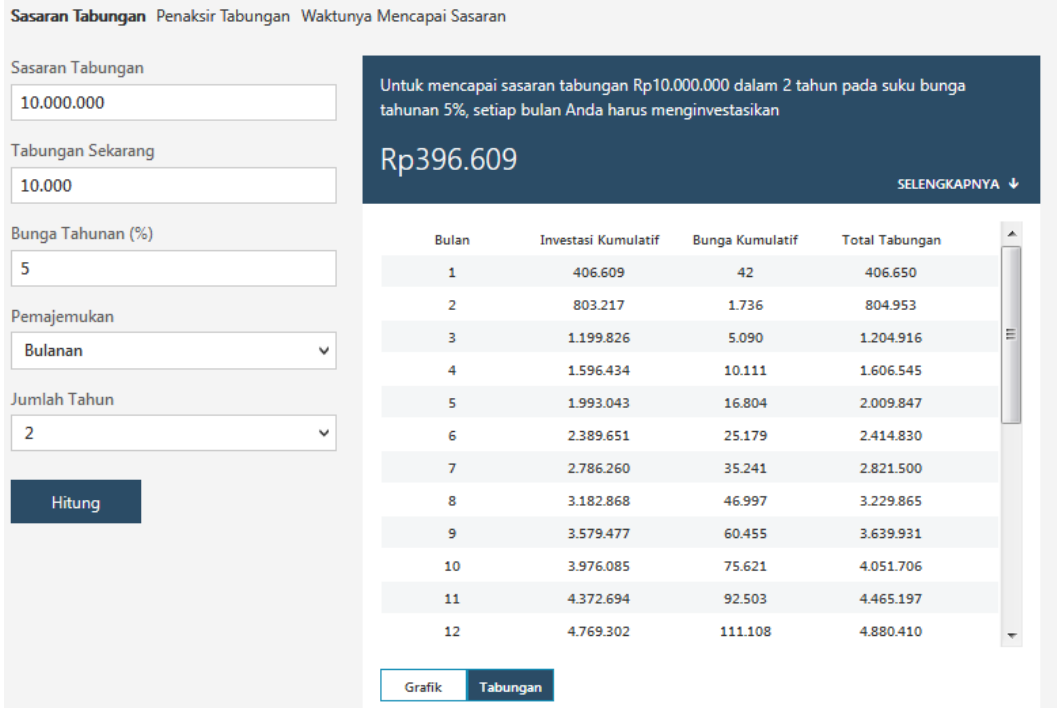

Sasaran Tabungan Penaksir Tabungan Waktunya Mencapai Sasaran

Sasaran Tabungan

10.000 .000

Tabungan Sekarang

10.000

Bunga Tahunan (\%)

5

Pemajemukan

Bulanan $\checkmark$

Jumlah Tahun

2

Hitung
Untuk mencapai sasaran tabungan Rp10.000.000 dalam 2 tahun pada suku bunga

tahunan 5\%, setiap bulan Anda harus menginvestasikan

\section{Rp396.609}

SELENGKAPNYA $\downarrow$

\begin{tabular}{|llll|}
12 & 4.769 .302 & 111.108 & 4.880 .410 \\
13 & 5.165 .911 & 131.443 & 5.297 .354 \\
14 & 5.562 .519 & 153.515 & 5.716 .035 \\
15 & 5.959 .128 & 177.332 & 6.136 .460 \\
16 & 6.355 .736 & 202.901 & 6.558 .637 \\
17 & 6.752 .345 & 230.228 & 6.982 .573 \\
18 & 7.148 .953 & 259.323 & 7.408 .276 \\
19 & 7.545 .562 & 290.190 & 7.835 .752 \\
\hline 20 & 7.942 .170 & 322.839 & 8.265 .010 \\
\hline 21 & 8.338 .779 & 357.277 & 8.696 .056 \\
\hline 22 & 8.735 .387 & 393.510 & 9.128 .898 \\
\hline 23 & 9.131 .996 & 431.548 & 9.563 .543 \\
\hline 24 & 9.528 .604 & 471.396 & 10.000 .000 \\
\hline Grafik & & & \\
\hline
\end{tabular}

Sumber: www.msn.com (2018)

Gambar 1. Percobaan Dengan Kalkulator Tabungan 


\section{Identifikasi Masalah}

Masalah yang dapat diidentifikasi dalam penelitian ini adalah sebagai berikut:

1. Pengetahuan akan manfaat dan tujuan menabung perlu diedukasi sejak dini pada anak. Selama ini anak hanya diedukasi akan pentingnya disiplin menabung, namun kurang diedukasi mengenai kemampuan jumlah yang ditabung dalam mewujudkan cita-cita. Hal ini menjadi penting pada anaknaka yang memiliki keterbatasan (berada di tempat penampungan).

2. Bentuk edukasi yang diperlukan bagi anakanak usia dini tidak tepat bila diberikan dengan metode orang dewasa. Perhitungan jumlah yang rumit dengan alat hitung tradisional seperti kalkulator atau menggunakan rumus hitung manual akan membuat anak kurang tertarik. Alat hitung tabungan yang dekat dan menarik buat anak dirasa perlu dilakukan, salah satunya dengan menggunakan pendekatan informasi berbasis digital.

\section{Tujuan dan Manfaat Penelitian}

Tujuan dari penelitian ini adalah:

1. Menjelaskan efektivitas materi dan implementasi materi pelatihan yang tepat dengan topik sadar finansial menabung pada anak menggunakan informasi digital.

2. Menjelaskan kemampuan dari instruktur dalam membawakan pelatihan dengan topik sadar finansial menabung pada anak menggunakan informasi digital.

\section{Jenis Penelitian}

\section{METODE PENELITIAN}

Penelitian ini merupakan penelitian kuantitatif deskriptif. Penelitian ini diharapkan dapat menjelaskan efektivitas program pelatihan dalam upaya mengetahui tujuan menabung sejak dini berdasarkan nilai tabungan dengan Kalkulator Tabungan yang diberikan melalui kegiatan Pengabdian Kepada Masyarat (PKM). Deskripsi hasil akan dijelaskan melalui 2 (dua) bagian penting yaitu efektivitas kemasan program dan kemampuan peneliti dalam memberikan pelatihan tersebut. Kedua bagian tersebut sesuai dengan standar yang dibuat oleh penyelenggara kegiatan PKM.

\section{Pengumpulan Data}

Data dikumpulkan pada saat pelaksanaan PKM yaitu pada tanggal 27 Desember 2017.
Tempat kegiatan PKM berada di Panti Asuhan Sosial Wijaya Kusuma yang terletak di Gadog, Pacet Kabupaten Cianjur, Jawa Barat. Populasi dari penelitian ini adalah seluruh anak yang diasuh di Panti Asuhan tersebut. Responden yang menjadi sampel penelitian ini adalah para peserta PKM di tempat tersebut yang berjumlah 31 anak. Populasi total tidak dapat dilakukan karena sebagian anak tidak berada di tempat karena berbagai alasan, salah satunya dibawa sanak keluarga untuk liburan. Profil responden adalah anak yang berada pada kelompok usia Sekolah Dasar (SD) sampai dengan Sekolah Menengah Atas (SMA).

\section{Teknis Analisis Data}

Penelitian ini menggunakan survei dengan instrumen kuesioner. Kuesioner terdiri dari 10 (sepuluh) item yang berasal dari 2 faktor penting yaitu materi program dan kemampuan narasumber (pelatih). Skala yang digunakan dalam kuesioner ini terdiri dari 4 (empat) rentang yaitu 1-4. Pengolahan data dilakukan dengan menggunakan Statistical Package for Social Science (SPSS) versi 24. Statistik deskriptif dalam penelitian ini menggunakan analisis potret data (frekuensi dan persentase), analisis kecenderungan sentral data (rata-rata, median dan modus) dan analisis variasi nilai (kisaran dan simpangan baku atau varian).

\section{HASIL DAN PEMBAHASAN}

Hasil penelitian ini menjelaskan Tabel output di atas menunjukkan ukuran penyebaran data (dispersi) berdasarkan jumlah pengukuran $(\mathrm{N})$, nilai minimum (Minimum), nilai maksimum (Maximum), nilai rata-rata (Mean), standar deviasi (Std.), Skewness, dan Kurtosis.

Kolom Minimum menggambarkan bahwa nilai terendah untuk setiap faktor yang ada dalam penelitian ini sebesar 1 dan nilai tertinggi dalam penelitian ini sebesar 4. Angka rata-rata paling rendah dalam penelitian ini sebesar 3,00 dan angka rata-rata tertinggi dalam penelitian ini sebesar 3,38. Standar deviasi pada tabel tersebut dapat menjelaskan keragaman (heterogen) pada data dalam penelitian. Pada standar deviasi semakin besar angka pada standar deviasi maka dapat dijelaskan pula semakin besar jarak rata-rata tiap unit data yang ada terhadap rata-rata hitung (mean) yang ada.

Tabel tersebut juga menjelaskan bahwa kolom skewness dapat menggambarkan ukuran kesimetrisan histogram, sedangkan kurtosis 
dapat menggambarkan ukuran datar atau runcingnya histogram. Jika nilai skewness bertanda positif maka distribusi data "miring ke kiri distribusi normal" (ada frekuensi nilai yang tinggi di sebelah kiri titik tengah distribusi normal), sebaliknya apabila skewness bertanda negatif maka distribusi data "miring ke kanan distribusi normal". Jika nilai kurtosis positif maka distribusi data "meruncing" (ada satu nilai yang mendominasi), sebaliknya apabila Kurtosis Negatif maka distribusi data "melandai" (varians besar). Data dapat dikatakan normal apabila angka rasio pada skrewness berada pada rentang angka -2 sampai dengan 2. Pada tabel tersebut menunjukkan hasil yang semuanya masih berada pada rentang yang ditentukan. Pada kolom kurtosis dapat dijelaskan mengenai angka keruncingan data penelitian yang ada. Keruncingan data dapat dikelompokan dalam 3 bagian, yaitu leptokurtic (memiliki angka >3), mesokurtic (memiliki angka = 3), platykurtic (memiliki angka <3). Berdasarkan hasil kolom yang ada dapat dijelaskan bahwa kemiringan data dalam penelitian ini bersifat Platykurtic (MI1, MI2, MI3, MI5, MITotal, IN1, IN2, IN3,IN4,IN5, INTotal), dan Mesokurtic (MI4).

Tabel 2. Statistik Deskriptif

\begin{tabular}{|c|c|c|c|c|c|c|c|c|c|}
\hline & $N$ & Minimum & Maximum & Mean & $\begin{array}{l}\text { Std. } \\
\text { Deviation }\end{array}$ & Skewness & & Kurtosis & \\
\hline & Statistic & Statistic & Statistic & Statistic & Statistic & Statistic & $\begin{array}{c}\text { Std. } \\
\text { Error }\end{array}$ & Statistic & $\begin{array}{c}\text { Std. } \\
\text { Error }\end{array}$ \\
\hline MI1 & 31 & 2.00 & 4.00 & 3.3548 & .55066 & -.015 & .421 & -.786 & .821 \\
\hline MI2 & 31 & 2.00 & 4.00 & 3.2581 & .51431 & .347 & .421 & -.226 & .821 \\
\hline MI3 & 31 & 2.00 & 4.00 & 3.0645 & .57361 & .015 & .421 & .336 & .821 \\
\hline MI4 & 31 & 1.00 & 4.00 & 3.0645 & .62905 & -.903 & .421 & 3.263 & .821 \\
\hline MI5 & 31 & 2.00 & 4.00 & 3.3871 & .61522 & -.457 & .421 & -.563 & .821 \\
\hline MITotal & 31 & 13.00 & 20.00 & 16.1290 & 1.62772 & .423 & .421 & -.345 & .821 \\
\hline IN1 & 31 & 2.00 & 4.00 & 3.2258 & .56034 & .053 & .421 & -.103 & .821 \\
\hline IN2 & 31 & 1.00 & 4.00 & 3.0000 & .68313 & -.671 & .421 & 1.537 & .821 \\
\hline IN3 & 31 & 2.00 & 4.00 & 3.1613 & .45437 & .711 & .421 & 1.265 & .821 \\
\hline IN4 & 31 & 2.00 & 4.00 & 3.2258 & .61696 & -.166 & .421 & -.399 & .821 \\
\hline IN5 & 31 & 1.00 & 4.00 & 3.2258 & .66881 & -1.006 & .421 & 2.871 & .821 \\
\hline INTotal & 31 & 11.00 & 20.00 & 15.8387 & 2.11497 & .384 & .421 & .289 & .821 \\
\hline Total & 31 & 27.00 & 40.00 & 31.9677 & 3.22990 & .507 & .421 & -.047 & .821 \\
\hline
\end{tabular}

Sumber: Hasil Pengolahan Data dengan SPSS 25, n=31

Berdasarkan tabel di atas juga dapat dijelaskan bahwa penelitian yang dilakukan melalui pengukuran media pelatihan yang dilakukan memiliki dua faktor penting yang 
dilibatkan yaitu Materi dan Implementasi (MI) dan Instruktur/Narasumber. Hasil dari masing- masing indikator dari kedua faktor tersebut dijelaskan sebagai berikut:

Tabel 3. Hasil Penilaian Rata-rata

\begin{tabular}{|c|c|c|}
\hline & Indikator & Penilaian Rata-rata \\
\hline \multirow{5}{*}{$\begin{array}{l}\text { Materi \& } \\
\text { Implementasi }\end{array}$} & Manfaat bagi peserta & 3,35 \\
\hline & Relevansi dengan tujuan & 3,26 \\
\hline & Ketepatan Media & 3,06 \\
\hline & Proses pelatihan & 3,06 \\
\hline & Penambahan pengetahuan & 3,39 \\
\hline \multirow{5}{*}{$\begin{array}{l}\text { Instruktur/nara } \\
\text { sumber }\end{array}$} & Penguasan materi & 3,23 \\
\hline & Penyampaian materi & 3,00 \\
\hline & Kemampuan penggunaan metode & 3,16 \\
\hline & Kemampuan menjawab pertanyaan peserta & 3,23 \\
\hline & Penciptaan suasana pelatihan yang mendukung & 3,23 \\
\hline
\end{tabular}

Sumber: Hasil Pengolahan Data dengan SPSS 25, n=31

Berdasarkan tabel di atas dapat dijelaskan bahwa secara rata-rata keseluruhan penilaian dari para peserta pelatihan terhadap topik "Sadar Finansial Pada Anak: Pelatihan Menggunakan Informasi Digital Dalam Menggali Tujuan Menabung" sudah baik. Hal ini dilihat dari rata-rata penilaian yang diberikan dimana dari skala 1 sampai dengan 4, peserta pelatihan memberikan angka di atas 3,00 (sebesar 3,23) untuk faktor ketepatan materi \& implementasi pelatihan dan juga di atas 3,00 (sebesar 3,17) pada faktor kemampuan instruktur. Beberapa indikator tertinggi dan terendah berdasarkan penilaian para peserta yaitu pada faktor Materi dan Implementasi, indikator "Penambahan Pengetahuan bagi Peserta" dan "Manfaat bagi Peserta" menjadi dua hal penting bagi peserta terhadap pelatihan yang diberikan yaitu 3,39 dan 3,35. Hal ini menjelaskan bahwa topik pelatihan ini merupakan salah satu topik yang dirasa perlu dan penting diberikan kepada para peserta. Peserta yang memiliki usia dini yang telah dibiasakan menabung perlu ditambah pengetahuannya dalam hal mengetahui target tabungan dan jumlah yang harus ditabung secara rutinnya. Anak-anak dalam usia kelompok ini memiliki cita-cita yang ingin diwujudkan baik yang berkaitan dengan kebutuhan primer ataupun sekunder. Namun demikian, para peserta yang berada di lingkungan panti menjadi tantangan yang cukup besar dalam pelaksanaan pelatihan. Hal ini dilihat dari indikator "Ketepatan Media" dan "Proses Pelatihan" sama-sama menjadi yang terendah yaitu sama-sama berada pada angka 3,06 . Topik dalam pelatihan ini secara langsung membutuhkan media gawai dan koneksi internet dalam implementasi materi dan familiaritas terhadap penggunaan teknologi gawai menjadi faktor tidak langsung. Melihat dari pelaksanaan pelatihan, kurang tersedia nya gawai dan koneksi internet menjadi kendala dalam efektivitas proses penyampaian materi. Para peserta memiliki kendala dalam kepemilikan gawai dan pengetahuan dalam menggunakan gawai berbasis internet.

Penguasaan materi yang diberikan, kemampuan menjawab pertanyaan dari peserta dan kemampuan menciptakan suasana pelatihan yang kondusif menjadi indiaktor tertinggi dalam penilaian peserta yang memiliki angka rata-rata 3,23. Hal ini menjelaskan juga bahwa instruktur/narasumber yang dihadirkan dalam membawakan topik "Sadar Finansial Pada Anak: Pelatihan Menggunakan Informasi Digital Dalam Menggali Tujuan Menabung" sudah baik (memiliki kompetensi). Selain itu, 
pendekatan dengan para peserta yang merupakan anak didik panti juga berhasil dilakukan sehingga suasana pelatihan dapat tercipta dengan kondusif. Pertanyaanpertanyaan yang diajukan dapat digambarkan memiliki karakter keingintahuan dan motivasi dalam tujuan menabung, misalnya: "kalau saya menabung tidak rutin dengan jumlah yang tidak pasti, apakah saya bisa membeli barang yang saya inginkan nanti?". Pertanyaan seperti ini dijawab dengan memberikan cerminan perbandingan jumlah tabungan (perhitungan dengan kalkulator tabungan berbasis daring dengan memasukan faktor jumlah tabungan yang ada, jumlah yang akan rutin ditabung tiap periodenya dan lama menabung) dengan harga barang yang diinginkan. Hasil ini berhasil memberikan gambaran kepada peserta pelatihan dengan usia dini untuk mengetahui berapa jumlah yang sebaiknya ditabung dengan target jangka waktu tertentu. Angka-angka perhitungan tersebut juga dapat memberikan motivasi kepada para peserta dalam memaknai arti menabung yang dimulai dari kesadaran diri akan menabung untuk mencapai tujuan yang diinginkan.

Sedangkan indikator "Penyampaian materi" menjadi kendala yang dihadapi dalam pelaksanaan pelatihan. Hal ini dilatarbelakangi oleh tempat dan alat yang mendukung proses penyampaian materi dalam pelatihan tersebut bukan tempat untuk pelatihan pada umumnya, ditambah lagi dengan menggunakan gawai berbasis internet. Kemampuan peserta dalam menggunakan gawai yang terkoneksi dengan internet dalam penggunaan informasi berbasis digital untuk menghitung angka tabungan yang diinginkan masih menjadi catatan penting bagi pelaksana. Informasi awal mengenai karakter pelatihan dan peralatan yang diperlukan rasanya perlu untuk disampaikan kepada

\section{DAFTAR PUSTAKA}

BNI Taplus Anak. (2018). Retrieved Januari 25, 2018, from http://www.bni.co.id: http://www.bni.co.id/idid/personal/simpanan/bnitaplusanak

bri.co.id. (2018). Tabungan BRI Junio. Retrieved Januari 25, 2018, from http://bri.co.id: peserta sebelum hari pelaksanaan pelatihan. Hal ini bertujuan untuk mendapatkan proses pelatihan yang lebih efektif. Hasil dalam penelitian ini sedikit banyaknya berkaitan dengan hasil penelitian yang dilakukan oleh Mulya, Indarto, \& Febrialismanto (2016) yang menjelaskan bahwa bentuk praktik/pelatihan seperti penggunaan tabungan kepingan dapat memberikan dampak pada motivasi disiplin menabung pada anak usia 4-5 tahun di Payakumbuh. Bentuk-bentuk simulasi, praktek, ataupun pelatihan dalam menciptakan ataupun menciptakan kesadaran finansial (menabung) pada anak-anak dapat beragam dan sebaiknya dipilih dengan tepat sesuai dengan kondisi tempat dan peserta.

\section{SIMPULAN}

Berdasarkan analisis dan pembahasan di atas, maka simpulan dalam penelitian ini adalah sebagai berikut:

1. Materi dan implementasi topik pelatihan "Sadar Finansial Pada Anak: Pelatihan Menggunakan Informasi Digital Dalam Menggali Tujuan Menabung" dirasa sudah tepat sasaran. Hal ini dilihat dari hasil penilaian yang diberikan oleh para peserta pelatihan, khususnya dalam memberikan manfaat dan pengetahuan lebih bagi para peserta. Namun hal ketepatan media dan proses penyampaian nya dirasa perlu dikoordinasikan kepada pelaksana dan para peserta sebelum hari pelaksanaan pelatihan.

2. Faktor kemampuan instruktur/narasumber dalam penguasaan materi dirasa sudah baik berdasarkan penilaian dari peserta. Sama dengan hasil pada poin pertama di mana alat pendukung penyampaian pelatihan dirasa perlu untuk disesuaikan antara kebutuhan dan tersedianya alat yang dimiliki peserta.

http://bri.co.id/index.php/subpage/deta ils?id=14

cimbniaga.com. (2018). Junior and Youth. Retrieved Januari 25, 2018, from https://www.cimbniaga.com: https://www.cimbniaga.com/in/person al/banking-with-us/junior-andyouth.html

Fuad, H. (2017, Oktober 20). http://koransindo.com. Retrieved Januari 25, 2018, 
from MNC Bank Motivasi Anak Menabung sejak Dini: http://koransindo.com/page/news/2017-1020/2/8/MNC_Bank_Motivasi_Anak_ Menabung_sejak_Dini

Kaban, D. (2017, November 6). Anggota DPRD Karo Beri Motivasi Pentingnya Menabung Usia Dini. Retrieved Januari 25, 2018, from http://www.karoberita.com: http://www.karoberita.com/2017/11/an ggota-dprd-karo-beri-motivasipentingnya-menabung-usai-dini.html

kompas.com. (2011, April 30). Melatih Anak Sadar Finansial. (wawa, Editor) Retrieved Januari 25，2018, from http://tekno.kompas.com: http://tekno.kompas.com/read/2011/04 /30/17015935/melatih.anak.sadar.fina nsial

maybank.co.id. (2018). Tabungan Superkidz. Retrieved Januari 25, 2018, from https://www.maybank.co.id: https://www.maybank.co.id/consumer/ deposit/savingaccount/superkidz/Pages/MaybankSuperKidz.aspx

Mulya, F., Indarto, W., \& Febrialismanto. (2016). Pengaruh Penggunaan Tabungan Kepingan Terhadap Disiplin Pada Anak Usia 4-5 Tahun Di Tk Bungo Setangkai Kota Payakumbuh. Jurnal Online Mahasiswa (JOM) Bidang Keguruan dan Ilmu Pendidikan, 3(2), 1-14.
Rahman, I. (2017, April 4). Motivasi Anak Menabung Sejak Dini. (Edinayanti, Editor) Retrieved Januari 25, 2018, from http://banjarmasin.tribunnews.com: http://banjarmasin.tribunnews.com/20 17/04/04/motivasi-anak-menabungsejak-dini

Setiawan, S. R. (2013, Agustus 5). Ajari Anak Menabung, Ini Tipsnya. Retrieved Januari 25, 2018, from http://ekonomi.kompas.com: http://ekonomi.kompas.com/read/2013 /08/05/0915058/Ajari.Anak.Menabung .Ini.Tipsnya

Widjaya, M. (2012, Maret 6). Supaya Anak Rajin Menabung, Begini Caranya. Retrieved Januari 25, 2018, from http://www.republika.co.id: http://www.republika.co.id/berita/tren dtek/sains/10/05/26/gayahidup/parenting/12/03/06/m0gbhisupaya-anak-rajin-menabung-beginicaranya

www.msn.com. (2018). Kalkulator Tabungan. Retrieved Januari 25, 2018, from https://www.msn.com: https://www.msn.com/idid/ekonomi/alat/kalkulatortabungan

www.panin.co.id. (2018). Tabungan Junior. Retrieved Januari 25, 2018, from http://www.panin.co.id: http://www.panin.co.id/pages/96/tabun gan-junior-panin 